\title{
НИКОЛАЙ РУДЕНКО \\ ОТ ЗАБВЕНИЯ ДО КАМНЕЙ \\ ПРЕТКНОВЕНИЯ И ОБРАТНО:

\author{
АНАЛИЗ КОНТРОВЕРЗЫ ВОКРУГ КАЛИНИНГРАДСКОЙ БРУСЧАТКИ \\ ЧЕРЕЗ ПРИЗМУ ПРАГМАТИЧЕСКОЙ СОЦИОЛОГИИ
}

Руденко Николай Иванович, кандидат социологических наук, научный сотрудник Центра исследований науки и технологий Европейского университета в Санкт-Петербурге; аффилированный сотрудник Социологического института РАН (филиала ФНИСЦ РАН); Российская Федерация, 191187, Санкт-Петербург, ул. Гагаринская, д. 6/1, литера А.

E-mail: diogenstyx@gmail.com

Статья посвящена описанию и анализу ситуации контроверзы вокруг исторического брусчатого покрытия в городе Калининграде в 2010-2013 годах. В 2010-е годы в Калининграде начинается массовое асфальтирование улиц с немецкой брусчаткой, что вызывает недовольство и протесты горожан. Это приводит к появлению первого в городе активистского гражданского движения по защите города и исторического наследия «Спасем брусчатку!». Статья описывает условия появления этого движения, его динамику и причины исчезновения. В качестве теоретической рамки предлагается опереться на французскую традицию прагматической социологии. Так, главный фокус статьи сосредотачивается на том, как разворачивается контроверза вокруг вопроса «Сохранять или убирать историческую брусчатку с улиц города?». Обсуждается, какие ресурсы использует каждая из сторон (городская администрация и активистское движение), какие нормативные, институциональные и политические ограничения делают возможной или сужают критику действий городской администрации. В ходе исследования, опиравшегося на метод кейс-стади, были собраны 10 интервью с участниками движения, а также журналистами, архитекторами, инженерами и т.д., сделан анализ местной периодики, собраны и проанализированы посты и документы в онлайн-группе активистов. Статья показывает, что критика действий власти стала возможной благодаря СМИ, социальным сетям, обращениям к чиновникам, но при этом она была ограничена нормативными документами и административными барьерами.

Ключевые слова: городской активизм; прагматическая социология; брусчатка; Калининград

Цитирование: Руденко Н.И. (2020) От забвения до камней преткновения и обратно: анализ контроверзы вокруг калининградской брусчатки через призму прагматической социологии//Городские исследования и практики. Т. 5 . № 2. C. 50-70. DOI: https://doi.org/10.17323/usp52202050-70

\section{Введение}

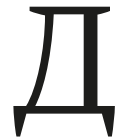

о того, как случились события, о которых пойдет речь в данной статье, то есть до 2010-2011 годов, в Калининграде не было сплоченной группы городских активистов, которые бы боролись за сохранение историко-культурного наследия города. Не было здесь и разделяемого всеми представления о брусчатке как важной части исторического наследия города. До 2010 года городская администрация едва ли жила в мире горожан и не пыталась говорить на их языке.

В 2017 году, когда автор данной статьи приехал в Калининград брать интервью о старинной немецкой брусчатке, в городе уже было городское активистское движение, которое боролось за трамвай, брусчатку, аллеи и другие важные для горожан объекты. Брусчатка стала культурной ценностью города, по крайней мере в дискурсивном пространстве. Городская администрация научилась говорить с горожанами.

Какие события в 2011-2013 годах привели к такой трансформации? Если говорить коротко появилось движение «Спасем брусчатку!», которое изменило представление о том, что такое брусчатка Калининграда, и изменило паттерны коммуникации чиновников. Однако, несмотря на это, главная цель движения - создать долговременную стратегию обращения с брусчаткой и в перспективе со всем историческим наследием Восточной Пруссии - провалилась.

В данной статье успех и провал движения анализируются с позиции французской прагматической социологии. 


\section{Прагматическая социология города}

Чтобы сделать понятными основные идеи прагматической социологии в контексте города, я начну с контрастного подхода городской социологии антропологического толка, а именно с работы городского антрополога Сеты Лоу. Лоу - один из классиков современных городских исследований, и в ее творчестве можно найти многие допущения, свойственные и для других городских теорий. Для Лоу важна дихотомия между видением города как машины роста и города, с одной стороны, как пространства повседневности, а с другой - как места памяти [Тыканова, 2013]. В концептуальном плане Лоу опирается на дихотомию «социальное производство - социальное конструирование». Эта дихотомия строится на идее того, что в городе есть «сильные» акторы, например федеральная и муниципальная власть и крупный бизнес, которые изменяют физическое, идеологическое, социальное и культурное пространство города, потому что обладают нужными ресурсами и видением. Однако в пространстве, которое они меняют, должны жить люди, «слабые» акторы, а у этих людей есть свое представление о пространстве, привычки, память. Когда пространство меняется сверху, это вызывает изменение подобных привычек и представлений и зачастую ведет к напряжению между акторами, и тем самым создается основание для активизма, критики и протестов [Low, 2000].

Прагматическая социология, на которой основана данная статья, проблематизирует все три элемента данного подхода, а именно: наличие сильных и слабых акторов, различение «производство - конструирование» и разделение на людей (которые протестуют) и вещи (по поводу которых спорят или которыми манипулируют во время протестов).

Ключевой момент прагматической социологии состоит в том, чтобы представить саму практику критики, оправдания и столкновения как продуктивный (перформативный) феномен, который перераспределяет власть, идентичности, компетенции и представления между участниками [Барт и др., 2019].

Так, после анализа кейса Пастера Бруно Латуром мы знаем, что сильные акторы не существуют с самого начала, они обретают силу, «заинтересовывая» других акторов и завязывая «союзнические» отношения с ними [Латур, 2002]. И, обратно, сильные акторы могут терять свою силу, если их союзники отказывают им в поддержке или если их попытки сделать себя представителями других (как людей, так и вещей) проваливаются [Каллон, 2015].

В той же мере неверно говорить о том, что некоторые акторы занимаются производством, а другие - конструированием (в том смысле, что у одних есть способность манипулировать физическими характеристиками, а у других - символическими, такими как память, образы и пр.). Такое видение кажется частью старинного спора, где экономическое и технологическое развитие отдано на откуп капиталу, инженерам и чиновникам, а рабочий класс при поддержке культурной интеллигенции опирается на культуру [Williams, 1983]. С позиции прагматической социологии такое деление неверно, поскольку, как покажет дальнейшая история, обе стороны опираются и на производство, и на конструирование. Необходимо рассматривать эти процессы не как изначально принадлежащие отдельным группам, а как результат выстроенных диспозитивов, одни из которых позволяют - в определенное время - производить город материально, а другие - творить его в воображении и дискурсе.

Наконец, третья дихотомия между людьми и вещами также не признается в качестве значимой в прагматической социологии. По крайней мере не так, как ее может видеть критическая городская социология или антропология города. Во-первых, отказываясь от наивного социального конструктивизма, прагматическая социология утверждает, что мы не можем знать наперед, какими характеристиками обладают вещи, особенно вещи, вовлеченные в спор, пока не закончился сам спор. Как покажет история дальше, на характеристики вещей влияет то, как разные стороны выстраивают сети поддержки: при помощи привлечения инженеров, архитекторов, строителей, чиновников, краеведов можно внутри спора артикулировать и сделать релевантными такие свойства вещей, которых раньше не было. Вторая важная особенность вещей заключается в том, что они способны выступать доказательствами в пользу компетентности тех или иных социальных агентов либо же опорой для критики в некомпетентности. Как мы покажем дальше, активисты «Спасем брусчатку!» несколько раз прибегали к брусчатке как, сначала, опоре для демонстрации Калининграда как города с большой историей 
и богатой историко-культурной средой; во-вторых, как к доказательству некомпетентности городской администрации в умении работать с городским пространством.

В отличие от критической социологии, прагматическая социология начинает с понятия спора. Повсеместность распространения критики в современных обществах говорит о том, что жители современных городов привыкли спорить и обосновывать свои позиции, и делают это относительно бескровно [Lemieux, 2018]. Чтобы отметить это, один из основоположников прагматической социологии, Люк Болтански, указывает на то, что любая критика начинается со своеобразного «скандала» - обвинения в нарушении какой-то важной для общества ценности (например, обвинения в коррупции). Однако затем вторая сторона, которую обвинили, почти всегда начинает доказывать свою невиновность или так или иначе высказывается по поводу обвинения. Таким образом, из «скандала» это превращается в «дело» или «историю» (affair), которые характеризуются тем, что есть две спорящие стороны, у которых есть собственные (зачастую непересекающиеся) видения того, что происходит.

Городские протесты почти всегда характеризуются именно тем, что на публичном уровне представляют собой «историю». Акторы с одной стороны, например активисты, выступают против какой-то инициативы по изменению городского пространства, обосновывая это своим набором аргументов (культурной ценностью), в то время как с другой стороны им отвечают другие акторы, например, муниципальная власть, которые обосновывают свои действия по изменению города указанием на свой набор аргументов (например, действие в соответствии со стандартами и регламентами). Многие исследователи сосредотачивают свое внимание на динамике, ресурсах и результатах этих споров и при этом упускают тот факт, что для понимания городской жизни могут быть важны дебаты сами по себе.

Многие из работ городских исследователей, ориентирующихся на прагматическую социологию, направлены на описание действия активистов и городской власти с целью выявить грады, к которым апеллируют агенты, либо режимы вовлеченности, в которых они находятся ${ }^{1}$ [Tykanova, Khokhlova, 2015; Tykanova, Khokhlova, 2019; Гладарев, 2012]. В основном концепты градов, миров, режимов вовлеченности используются как наиболее общие понятия, к которым сводятся отдельные эмпирические референты из поля: исследовательская работа направлена на то, чтобы соединить нарративы из интервью, СМИ и наблюдений с абстрактными градами или режимами, которые выделили классики прагматической социологии. Некоторые исследователи, к примеру петербургские социологи города Е. Тыканова и А. Хохлова, делают более интересные заходы, пытаясь объединить теоретические ходы прагматической социологии с другими теориями (например, теорией стратегических действий А. Хиршмана), демонстрируя вариации градов внутри разных действий (выход, голос или лояльность) [Tykanova, Khokhlova, 2015]. Однако даже эти, более интересные, теоретические решения страдают от излишней реификации тех или иных режимов вовлечения или градов оправдания. Кажется, что здесь упускается важнейший момент для прагматической социологии - пытаться описать то, как протекает спор, кто в нем участвует, как трансформируются позиции сторон и, что также важно, как меняется то, по поводу чего спорят конфликтующие стороны. Как отмечают сами основатели подхода, абстрактные грады являются лишь выражением, грубой моделью того, к чему отсылают люди (современных западных обществ) в своих спорах. Они не предзаданы, они могут меняться внутри ситуации, и потому их нужно не реифицировать и канонизировать, но рассматривать лишь как временные подспорья в разворачивающихся дискуссиях [Lетіеux, 2018].

Именно здесь возникает следующий важный аспект прагматической социологии - это вещи, вовлеченные в спор. Несмотря на то что практически все городские исследования протестов посвящены борьбе за городское пространство, в критических городских исследованиях очень редко встречаются отсылки к конкретным материальным характеристикам того, о чем спорят. Несмотря на то что сами агенты очень часто отсылают к материальным артефактам как к аргументам в свою пользу, исследователи чаще всего концентрируют свое внимание на том, какие интересы стоят за выбором артефактов, но не обращаются к состоянию или свойствам самих вещей. Между тем то, что отличает любой спор в современном мире, - это именно ука-

1 Понятие градов, миров и режимов вовлеченности не являются эквивалентными. Первые два понятия вводятся и разъясняются в [Болтански, Тевено, 2013]. Второе понятие берет начало в более поздних работах Л. Тевено [Thévenot, 2001]. 
зание на конкретное состояние вещей. Для спора о сохранении или сносе здания важны как аргументы с помощью слов, так и опора на материальные артефакты, чтобы доказать, что архитектура здания действительно старинная, что она дорога для жителей города, насколько она действительно ветхая и т.д. Как отмечает исследователь прагматической социологии Тома́ Бенатуй, «хотя вещи могут квалифицироваться и ими можно по-разному манипулировать, эти манипуляции в некоторой степени зависят от самих объектов - действия не могут быть какими угодно» [Bénatouil, 1999].

Вещи и люди не существуют отдельно, опираясь на собственную агентность и сталкиваясь иногда друг с другом. Вещи и люди обычно соединены вместе в определенных местах, создавая социальную и материальную «оснастку» для действия. Такая комбинация людей и вещей называется диспозитивом² [Болтански, Тевено, 2013; Lemieux, 2018]. Диспозитивы всегда определенным образом упорядочены. Идея Болтански и Тевено состоит в том, что в современном нам мире они упорядочены на основании градов, то есть общих коллективных принципов (рынка, гражданственности, патриархата и пр.). Однако сами по себе диспозитивы всегда могут быть раскритикованы: если в них нет слаженности действия, то они являются удачной опорой для критики (к примеру, плохое состояние дорог в городе служит основанием для критики муниципальной власти в некомпетентности), и, наоборот, связность людей и вещей внутри диспозитивов дает возможность отбиться от критики. Прагматическая социология опирается на идею диспозитива, чтобы указать на то, что действуют не социальные агенты как таковые. И, естественно, не вещи. Действуют диспозитивы людей и вещей.

Таким образом, прагматическая социология - это инверсия традиционной социологии: она заходит не со стороны социальных агентов (например, городской администрации, активистов, городских сообществ и т.д.), чтобы показать, как устроено их взаимодействие [Breviglieri, Stavo-Devauge, 1999]. Напротив, она сосредотачивается в первую очередь на действии (споре, серии актов, конфликте и т.д.), чтобы из него извлечь постепенно формирующиеся свойства и компетенции действующих диспозитивов. Именно в ситуации критики и обоснования, в ходе обвинений и демонстрации доказательств демонстрируются диспозитивы и сплоченность связей между ними. И потому вещи в таких спорах могут сыграть не менее решающую роль, чем люди.

В данной статье я использую озвученные выше методологические идеи прагматической социологии, чтобы проанализировать спор о калининградской брусчатке в 2011-2013 годах, в рамках которого был создан диспозитив гражданского движения в защиту города и по результатам которого брусчатка стала заметной частью историко-культурного наследия города.

\section{Данные и методы}

Данные были собраны в Калининграде в течение двух недель в конце мая - начале июня 2017 года. В ходе полевой работы было собрано 10 интервью с активистами движения «Спасем брусчатку!» (3) - архитекторами (2), журналистами (1), инженерами (1), краеведами (2), экспертами по городскому развитию (1). Многие из информантов участвовали в процессе защиты брусчатки в качестве активистов, но многие не имели к движению «Спасем брусчатку!» никакого отношения, это дало возможность создать более стереоскопическую картину произошедшего. Ограниченностью пула интервью является то, что мне не удалось взять интервью у городских чиновников. Однако мнения чиновников подробно приведены на страницах местных СМИ и даже в социальных сетях, которые также подробно анализируются.

Помимо формальных интервью проводились и фиксировались нерегулярные разговоры с жителями улиц с брусчаткой, а также таксистами Калининграда. Автор посетил музей «Фридландские ворота», книжный магазин с краеведческой литературой, прогулялся практически по всем брусчатым улицам Калининграда, делая записи о состоянии брусчатки на этих улицах и своих ощущений от нее. Была собрана периодика ведущих калининград-

2 Мы оставляем в русской версии именно это слово, поскольку слово «сеть» по сложившейся в России традиции будет отсылать либо к социальным сетям, либо к акторно-сетевой теории, что не совсем релевантно для прагматической социологии. В русском переводе главного труда Болтански и Тевено [Болтански, Тевено, 2013] также используется слово «диспозитив», так что мы здесь лишь продолжаем традицию. 
ских СМИ («Дворник», «Клопс», «Страна Калининград», «Новый Калининград», «Комсомольская правда. Калининград») за 2010-2017 годы - это издания, которые довольно много писали о брусчатке в городе и ситуации вокруг нее. Были проанализированы сообщения и документы в группе «Спасем брусчатку!» в социальной сети Facebook*, которая образовалась на волне активизма в 2012 году, в 2013-м стала менее активной, но до сих пор используется активными членами для коммуникации между собой и сообщений о новых действиях городской администрации.

Основной метод данного исследования - кейс-стади, где объектом выступила калининградская брусчатка как не бросающийся в глаза, но, что иронично, одновременно и самый заметный элемент городской среды. Подробно проанализировав все, что говорится и делается по поводу брусчатки, мне хотелось перейти к более общему суждению о том, как существует современный, хотя и уникальный российский город. Как в нем переплетены культурная логика, отсылающая к ценностям эстетики и истории, и технологическая логика с ее акцентом на эффективности, надежности и экономии? Каким образом возникают и почему проваливаются попытки изменить представление о городе и его функционировании?

Перед тем как я перейду к подробному описанию самого спора (контроверзы) вокруг брусчатки, важно коротко рассказать об истории калининградской брусчатки в досоветское время и в период СССР.

\section{История калининградской брусчатки}

Брусчатка, о которой идет речь в данной статье, - это немецкая брусчатка, которой укладывали дороги Кёнигсберга в 1920-1930-е годы. ${ }^{3}$ В досоветский период брусчатка выступала основным дорожным материалом, и в городе было очень много мастеров-тесальщиков и множество фирм, которые занимались нарезанием, обработкой и укладкой камней. Некоторые информанты отмечали, что укладывать брусчатку могли военнопленные и бедные рабочие [Инф. Т].

В советские годы, несмотря на то что шло постепенное избавление от «немецкого» наследия (убирали надписи на немецком, при приезде высокопоставленных советских чиновников закрашивали красные черепичные крыши, в 1967 году взорвали руины Кёнигсбергского замка), брусчатка не убиралась с калининградских дорог. В итоге, как отмечает в интервью калининградский краевед, в этот период брусчатка воспринималась утилитарно: она была исключительно частью городской инфраструктуры и никак не проявлялась в качестве исторической или культурной ценности [Инф. И].

Интерес к брусчатке как к культурной достопримечательности и символу региональной специфики возник в 1990-е годы. По словам одного из информантов, в этот период из брусчатки стали не только выкладывать дорожки на дачах, но и строить целые заборы и даже башни.

Период 1990-2000-х годов показывает, что после распада СССР интерес к брусчатке в Калининграде проснулся. К ней впервые стали относиться не только как к дорожной инфраструктуре или объекту декора, но начали видеть в ней культурную ценность, а именно ценность чего-то немецкого и европейского. На это повлиял, например, тот факт, что брусчатые улицы в советском кинематографе ассоциировались с чем-то европейским, заграничным, престижным ${ }^{4}$ Дело было еще и в том, что в этот период начался процесс постепенного признания важности культурного наследия Германии для Калининграда. Оно становилось модным и ценным, а брусчатка была его составной частью. Несмотря на этот поворот в отношении к брусчатке, в медиапространстве города не было никакого дискурса, который говорил бы об историко-культурной ценности брусчатки. В той же мере городская власть относилась к брусчатке скорее как к дорожному материалу, время от времени заменяя ее на асфальт.

Если бросить взгляд на этот краткий исторический экскурс, то будет видно, что бывшая немецкая брусчатка не имела никакой значимости как историко-культурный объект. К началу

3 Калининград и Калининградская область (северная часть Восточной Пруссии) вошли в состав СССР в 1945 году по результатам Постдамской конференции. До 1946 года город назывался Кёнигсберг, но в 1946 году, после смерти Михаила Калинина, он был переименован в Калининград.

4 Подробнее об этом: [Димке, Руденко, 2017]. 
2010-х годов она была, по сути, историческим пережитком, который к тому же скорее мешал автомобилизации и строительному буму города, чем помогал ему5. Ее терпели как необходимость, и при наличии бюджета городская администрация старалась заменить ее на асфальт. Удивительно, учитывая все это, что уже через пару лет брусчатка станет одной из самых важных и обсуждаемых тем Калининграда, превратится в историческую достопримечательность города, а также спровоцирует городских активистов на то, чтобы предпринять весьма амбициозную попытку поучаствовать в развитии города.

Таблица 1. Основные этапы, события, результаты и диспозитивы спора вокруг калининградской брусчатки в 2010-2013 годах

\begin{tabular}{|c|c|c|c|c|}
\hline Период & Этап & Что произошло & Результат & $\begin{array}{c}\text { Основные диспози- } \\
\text { тивы спора } \\
\end{array}$ \\
\hline $\begin{array}{c}\text { Ноябрь - } \\
\text { декабрь } 2010 \\
\text { года }\end{array}$ & $\begin{array}{c}\text { Первый этап. } \\
\text { Первые столкно- } \\
\text { вения }\end{array}$ & $\begin{array}{c}\text { Жители Парковой } \\
\text { аллеи протестуют. } \\
\text { Встреча жителей } \\
\text { с мэром }\end{array}$ & $\begin{array}{c}\text { Отказ от асфальти- } \\
\text { рования Парковой } \\
\text { аллеи. Обсуждение } \\
\text { брусчатки в «Живом } \\
\text { журнале» } \\
\end{array}$ & $\begin{array}{c}\text { СМИ («Комсомольская } \\
\text { правда») }\end{array}$ \\
\hline $\begin{array}{c}\text { Январь - } \\
\text { декабрь } 2011 \\
\text { года }\end{array}$ & $\begin{array}{c}\text { Второй этап. } \\
\text { Нарастание про- } \\
\text { тестов }\end{array}$ & $\begin{array}{c}\text { Увеличение коли- } \\
\text { чества протестов. } \\
\text { Составление списка } \\
\text { улиц с брусчаткой } \\
\text { и его обсуждение }\end{array}$ & $\begin{array}{c}\text { Составление списка } \\
\text { улиц с брусчаткой; } \\
\text { опрос и критика } \\
\text { администрации } \\
\text { на форуме }\end{array}$ & $\begin{array}{c}\text { СМИ («Клопс», «КП»), } \\
\text { опрос, форум }\end{array}$ \\
\hline $\begin{array}{c}\text { Декабрь } 2011 \\
\text { года - январь } \\
2012 \text { года }\end{array}$ & $\begin{array}{c}\text { Третий этап. } \\
\text { Восхождение } \\
\text { к общему }\end{array}$ & $\begin{array}{c}\text { Появление движения } \\
\text { «Спасем брусчатку!». } \\
\text { Открытое письмо }\end{array}$ & $\begin{array}{c}\text { Восхождение } \\
\text { к общему - защите } \\
\text { исторического } \\
\text { наследия Калинин- } \\
\text { града } \\
\end{array}$ & $\begin{array}{l}\text { СМИ, опрос, форум, } \\
\text { группа «Спасем брус- } \\
\text { чатку!» в Facebook*, } \\
\text { открытое письмо }\end{array}$ \\
\hline $\begin{array}{l}\text { Январь - } \\
\text { август } 2012 \\
\text { года }\end{array}$ & $\begin{array}{c}\text { Четвертый этап. } \\
\text { Раскручивание } \\
\text { спора }\end{array}$ & $\begin{array}{c}\text { Спор между дви- } \\
\text { жением «Спасем } \\
\text { брусчатку!» и адми- } \\
\text { нистрацией Калинин- } \\
\text { града. Углубление } \\
\text { критики }\end{array}$ & $\begin{array}{c}\text { Брусчатка призна- } \\
\text { ется культурным } \\
\text { наследием дис- } \\
\text { курсивно. Созда- } \\
\text { ется Общественный } \\
\text { совет, намечается } \\
\text { регламент работы } \\
\text { с брусчаткой }\end{array}$ & $\begin{array}{c}\text { СМИ, форум, группа } \\
\text { «Спасем брусчатку!» } \\
\text { в Facebook*, коммуни- } \\
\text { кация с пресс-служ- } \\
\text { бой, встречи в гор- } \\
\text { администрации }\end{array}$ \\
\hline $\begin{array}{l}\text { Сентябрь } 2012 \\
\text { года - март } \\
2013 \text { года }\end{array}$ & $\begin{array}{c}\text { Пятый этап. } \\
\text { Закрытие спора }\end{array}$ & $\begin{array}{c}\text { Критика действий } \\
\text { движения в нор- } \\
\text { мативном, эксперт- } \\
\text { ном и техническом } \\
\text { измерении. Распад } \\
\text { движения }\end{array}$ & Распад движения & $\begin{array}{c}\text { СМИ, форум, группа } \\
\text { «Спасем брусчатку!» } \\
\text { в Facebook*, коммуни- } \\
\text { кация с заместителем } \\
\text { мэра; экспертный } \\
\text { круглый стол, откры- } \\
\text { тое письмо } \\
\end{array}$ \\
\hline $\begin{array}{c}\text { Март } 2013 \\
\text { года - совре- } \\
\text { менное } \\
\text { состояние }\end{array}$ & $\begin{array}{l}\text { Шестой этап. } \\
\text { Последствия } \\
\text { спора }\end{array}$ & $\begin{array}{l}\text { Сохранение куль- } \\
\text { турной ценности } \\
\text { брусчатки, появление } \\
\text { городского движения, } \\
\text { появление коммуни- } \\
\text { кативных способно- } \\
\text { стей администрации }\end{array}$ & $\begin{array}{c}\text { В публичном } \\
\text { дискурсе брусчат- } \\
\text { ка - историческое } \\
\text { наследие, в городе } \\
\text { появилось обще- } \\
\text { ственное движение, } \\
\text { администрация } \\
\text { научилась разгова- } \\
\text { ривать с жителями }\end{array}$ & $\begin{array}{l}\text { СМИ, группа «Спа- } \\
\text { сем брусчатку!» } \\
\text { в Facebook* }\end{array}$ \\
\hline
\end{tabular}

Источник: составлено автором на основе анализа эмпирических данных.

5 Как отмечает в интервью инженер-строитель, в 1990-е годы в связи с бумом автомобилизации брусчатка скорее мешала развитию транспортной сети города, однако денег на ее массовую переукладку не было [Инф.T]. 


\section{Спор по поводу брусчатки ${ }^{6}$}

\section{Первый этап. Первые столкновения}

Фокусированное, но эпизодическое снятие брусчатки и ее замена на асфальт начинаются в Калининграде в 2000-е годы, что связано с выделением федеральных денег городскому бюджету [Денисенков, 2013]. В целом еще с советских времен существовала альтернатива замене брусчатки асфальтом - это перекладка брусчатки. Однако в 2000-2010 годы брусчатка именно снимается с нескольких улиц для замены на асфальт, что вызывает редкие протесты граждан. С 2010 года замена ведется активнее. Самый показательный случай - снятие брусчатки с одной из центральных и старых улиц города, Парковой аллеи. Жители этой улицы протестуют против демонтажа брусчатки, что приводит к столкновениям с компанией, которая занимается демонтажем брусчатки. Конфликт приобретает общегородской масштаб, когда в нему подключаются журналисты местной «Комсомольской правды», которые организуют акцию «Спасем брусчатку старого города!», а также печатают разноречивые мнения о необходимости брусчатки. Чтобы уладить конфликт с жителями Парковой аллеи, с ними встречается мэр города, после встречи он решает приостановить асфальтирование улицы. «Комсомольская правда» в рамках этого спора публикует мнение жителей улиц с брусчаткой и экспертов об этом покрытии. В защиту своей позиции оставить камни на улицах опрошенные отсылают и к физическим свойствам брусчатки (сцепление колес с камнем лучше, чем с асфальтом, это более устойчивое покрытие) и к ее историко-культурным свойствам (она придает своеобразие Калининграду).

Также мэр публикует в своем «Живом журнале» пост о том, что «булыжные мостовые, за сохранение которых выступают жители, действительно являются следами прошлого на наших улицах», но далее он пишет, что перекладывать брусчатку - тяжелый труд, специалистов для этого мало, а для самого города это дорого [Про брусчатку, 2010]. Он приходит к выводу, что нужно либо тратить деньги на дорогой ремонт исторического покрытия, либо асфальтировать дороги. Важно отметить, что уже в этом посте мэр вводит различение между улицами с интенсивным движением и историческими мостовыми. Под его постом набирается 83 комментария как от защитников брусчатки, так и от тех, кто выступает за асфальтирование улиц.

Таким образом, в ходе первого столкновения жителей Парковой аллеи и мэра города по поводу брусчатки мы видим, как формируются группы сторонников и противников снятия брусчатки, проявляются диспозитивы (СМИ, «Живой журнал»), которые обеспечивают возможность критики и споров. Однако основные действия будут происходить уже после.

\section{Второй этап. Нарастание протестов}

В 2011 году брусчатку продолжают снимать, при этом вслед за спальными историческими районами захватывают и центр города - небольшие придомовые улицы (ул. 1812 года, ул. Космическая) и широкие и оживленные магистрали (улица 9 Апреля). Снятие сопровождается протестами жителей улиц, где это происходит. Не только «Комсомольская правда», но и местное издание «Клопс» организует кампанию по составлению списка улиц, где еще лежит брусчатка [Составим список..., 2011]. В свою очередь, администрация города пытается провести свое исследование общественного мнения по поводу брусчатки: в управляющие компании поступает обращение изучить мнение жильцов о брусчатке.

Летом 2011 года городская администрация проводит оперативное совещание, где принимает решение успокоить граждан, но при этом продолжить снимать брусчатку. Это делается с помощью такого объекта, как список улиц. К концу 2011 года архитекторы и чиновники администрации предложат два списка улиц: один будет включать улицы, где нужно оставить брусчатку, второй - где ее нужно убрать. При этом оба заместителя мэра выражали негативное отношение к брусчатке, приводя разные доводы: сомнения в ее прочности и безопасности,

6 В силу того, что количество знаков в статье ограничено, я не буду ссылаться на все СМИ, которые использовались в качестве источников. Я буду давать ссылку только на самые важные для данной истории тексты. В табл. 1 для удобства сведены все этапы, события, результаты и диспозитивы, о которых я рассказываю в этом параграфе. 
а также то, что жителям улиц с брусчаткой неудобно по ней ходить в сандалиях, возить коляски и ездить на велосипеде [Власти предлагают..., 2011].

В конце года, 28 декабря, администрация опубликовала на своем сайте файл Excel, где был приведен список из 106 улиц города с брусчаткой, 46 из них были отмечены как требующие асфальтирования, а остальные 60 было запланировано оставить с брусчаткой. К файлу было приложено голосование и открыто обсуждение на форуме администрации для комментариев. Жителям отвели два месяца на обсуждение на форуме, после чего список улиц должны были передать для утверждения в Окружной совет депутатов (местный законодательный орган).

К содержанию голосования (и его результатам) доступа получить, к сожалению, не удалось, сами результаты были удалены с сайта городской администрации, хотя другие опросы находятся там до сих пор [Onpocbl, 2020]. Однако комментарии на форуме доступны. На момент исследования в 2017 году там было оставлено 350 сообщений, причем много сообщений было сделано уже после того, как голосование закрылось. Чтение комментариев показывает, что мнения горожан кардинально разделились, и брусчатка стала объектом споров.

Десятки аргументов были высказаны на форуме за и против брусчатки на улицах городов. Среди аргументов за: брусчатка создает в городе уникальную атмосферу, она красивая, она - отголосок истории, экологична, в Европе от брусчатки не избавляются, брусчатка - это «естественный» тормоз, который не позволяет лихачам гонять по городу на большой скорости. Противники брусчатки отмечали среди прочего, что брусчатка шумна, создает пробки, быстро проседает, портит машины, что на нее нельзя нанести разметку [Форум, 2020].

Подытоживая этот этап развития публичного спора, стоит отметить, что организованными ею голосованием и обсуждением администрация города открыла «ящик Пандоры». Во-первых, комментарии на форуме показали, что защитников брусчатки действительно много ${ }^{7}$ Во-вторых, многие пользователи писали не о брусчатке, а о разочаровании от того, как администрация работает с общественностью. Иными словами, критике подвергся не объект спора, а сам диспозитив организации спора. Так, одна из пользовательниц писала: «Согласна со всеми, кто уже написал выше о том, что это не опрос вовсе. Каким образом мы увидим реальное количество проголосовавших за брусчатку и против нее????!!! В общем, очередная фальсификация» [Форум, 2020]. В-третьих, во многих комментариях пользователи писали не о судьбе брусчатки, а подвергали сомнению способность городской администрации работать с брусчаткой из-за коррупции или низкой компетенции. Наконец, в-четвертых, это обсуждение стало площадкой, на которой начало постепенно формироваться инициативное движение, впоследствии ставшее «Спасем брусчатку!». Многие из будущих участников этого движения высказывали свое мнение на форуме, а некоторые даже предложили программу общественного движения в защиту брусчатки. В следующем параграфе будет рассказано, как оно появилось.

\section{Третий этап. Восхождение к общему}

Организация инициативной группы по защите брусчатки стала следствием критики планов администрации по массовой замене брусчатки на асфальт, ее неспособности вести диалог с общественностью, а также отсутствию у нее планов работы с историческим наследием Калининграда. Одна из участниц «Спасем брусчатку!» в интервью отмечала, что брусчатка была точкой консолидации горожан, недовольных политикой администрации в отношении не только брусчатки, но и всего исторического наследия города [Инф. О]. По словам другой участницы, процесс принятия решения по поводу замены брусчатки асфальтом не был открытым. И когда администрация города опубликовала «голосование» и «все увидели количество улиц и в том числе многие увидели свои улицы, то почувствовали угрозу тому, что существенная часть историко-культурного облика города исчезнет, и тогда возникла какая-то критическая масса народа активного, которая сказала: “Ну давайте все-таки не дадим этого сделать!” [Инф.Л.].

Заслуга движения «Спасем брусчатку!» заключалась в том, что оно способствовало повышению уровня обсуждения - с вопроса о сохранении брусчатки на отдельных улицах, акту-

7 Примерный порядок соотношения защитников и противников брусчатки такой: около 70\% комментариев было за сохранение, 25\% - за замену на асфальт, около 5\% - предлагали компромиссные варианты. 
ального в 2010-2011 годах, перешли к проблеме сохранения историко-культурного наследия Калининградской области в целом. В прагматической социологии это называется «восхождение к общему» [Lemieux, 2018]. Публичные споры, говорят сторонники этого направления, требуют того, чтобы они шли по поводу публичного блага, которое разделяется многими. А это предполагает превращение индивидуальных проблем в коллективные. Брусчатка, которую снимали с улиц, могла вызвать недовольство отдельных людей, которым они могли делиться даже на страницах газет. Но оно все еще оставалось индивидуальным недовольством. Движение «Спасем брусчатку!» превратило его в коллективное недовольство, но не просто политикой в отношении брусчатки, а политикой в отношении всего культурного наследия города.

Кроме того, движение расширило репертуар диспозитивов спора. Активисты организовали группу в Facebook**, где стали собирать, анализировать и обсуждать проблемы, связанные с демонтажем брусчатки, а также с историческим наследием в целом. Они написали открытое письмо губернатору Калининградской области, председателю Калининградской областной Думы и мэру города [Обращение, 2012]. Авторы письма обвиняли городскую администрацию в том, что ее политика в отношении культурного наследия фрагментарная и недальновидная, что она попусту тратит бюджетные деньги (на ремонт улиц, где ремонт не нужен), что понастоящему не прислушивается к мнению жителей.

Однако обвинениями авторы не ограничились: тогда бы и самого движения не существовало. В заключительной части письма подписавшиеся изложили предложения (по сути, требования), которые стали программой движения на следующий год его существования. Важно выделить три из них:

1. Приостановить замену брусчатки на асфальт до принятия «общественно-приемлемых решений».

2. Создать рабочую группу по решению вопроса брусчатки.

3. Отнести брусчатку к объектам историко-культурного наследия.

Письмо было открытым, и его подписали 476 жителей Калининграда и других городов, включая директоров музеев, архитекторов, университетских профессоров, заслуженных художников, редакторов газет и т.д. Сторонники движения «Спасем брусчатку!» не только смогли совершить восхождение к общему в открытом письме, но и собрали сильную команду «союзников», которые были заинтересованы в решении проблемы с брусчаткой. В отличие от анонимов на форуме городской администрации, от которых можно было легко отмахнуться, это были конкретные люди (в том числе очень статусные), которые были недовольны и которым нужно было что-то ответить.

Уже через 10 дней после публикации письма мэр города встретился с активистами из движения «Спасем брусчатку!».

Таким образом, на данном этапе всего за месяц (декабрь 2011 года - январь 2012 года) произошло «восхождение к общему»: индивидуальное недовольство жителей улиц, с которых снимали брусчатку, превратилось в коллективную общественную инициативу по сохранению исторического наследия города. Это было достигнуто за счет объединения критики работы с брусчаткой и критики текущей работы городской администрации с общественным мнением.

Четвертый этап. Раскручивание спора

Следующий этап - с января по август 2012 года - характеризуется попытками разрешить спор «снимать или не снимать брусчатку с улиц Калининграда».

Однако первые встречи движения с мэром и его заместителями демонстрируют столкновение совершенно разных логик и «градов оправдания» [Болтански, Тевено, 2012]. На первой встрече заместитель мэра по архитектуре отмечал, что при решении вопросов оставления или снятия брусчатки нужно исходить из того, что «все-таки в XXI веке живем», то есть опираться на критерии комфорта, удобства и удовлетворенности горожан. Его основные аргументы касались того, что перекладывание брусчатки - это долгий процесс, для которого придется перекрывать улицу на длительный срок. Представительница движения «Спасем брусчатку!», напротив, попыталась сохранить переход к общему, который был сделан в открытом письме: она указывала, что проблема не в брусчатке, а в историческом облике города. Брусчатка и другие элементы истории города - это ресурс его развития. Если коротко, то с одной точки зрения 
брусчатка была частью городской инфраструктуры, а с другой - частью культурного наследия. Соответственно, каждое из этих видений определяло ответ на вопрос: оставлять или убирать?

На том же заседании мэр, несмотря на конфликтующие взгляды на брусчатку, предложил создать рабочую группу по работе с брусчаткой при главе города. Позднее этот орган был назван Общественным советом, о чем пиар-служба мэра отчитывалась на страницах городских газет. Главой совета был назначен заместитель мэра, который, как уже было заметно, видел в брусчатке почти исключительно городскую инфраструктуру. Участники движения были недовольны этим назначением.

Стоит сделать небольшое отступление. Почему мэр стал встречаться со сторонниками общественного движения? Многие участники этого движения и журналисты отмечали, что дело было в том, что в октябре 2012 года должны были пройти выбора мэра. Вероятно, в связи с этим в начале 2012 года действующий мэр, который стремился переизбраться, начал серию встреч с «представителями общественности». Мэр встречался с недовольными садоводами, предпринимателями, молодежью, военно-патриотическими организациями. «Защитники брусчатки» также оказались среди тех, с кем была организована коммуникация. Речь идет о действительно полноценной коммуникации: для этого мэр наделил свою пиар-службу обязанностями организовать постоянные встречи инициативной группы с ним и его заместителями и передавать ему от движения «Спасем брусчатку!» документы и обращения. По сути, использование пиарслужбы для коммуникации сильно сокращало время общения между мэром и движением. Таким образом, можно отметить, что диспозитив спора был еще больше расширен. К группе в Facebook*, форуму на сайте администрации, городским газетам и открытому письму добавился прямой канал коммуникации с пресс-службой мэра [Инф. Л].

Однако последующие взаимодействия с мэром и его заместителями привели лишь к углублению спора, но не к его разрешению. Это видно по встрече рабочей группы, которая состоялась в конце января. Она показательна по двум причинам. Во-первых, участники движения предложили свою версию Общественного совета с предложением состава, организации работы, задач данного органа. В предложении инициативной группе Совет должен формироваться из граждан Калининграда, которым интересно участвовать в нем; председатель избирается общим голосованием; Совет занимается стратегией развития Калининграда, в первую очередь развитием историко-культурного наследия.

Однако данное предложение было отклонено представителями администрации города. Главный аргумент в пользу отклонения - и он станет очень важным для всей коммуникации городской администрации и активистов - состоял в том, что по закону совет не мог подменять функции органов государственной местной власти. Иначе говоря, решения Совета могли иметь только рекомендательный характер. Во-вторых, в Общественный совет нужно было обязательно включать чиновников и депутатов Окружного совета, причем они обязательно должны были быть председателями и секретарями. Этот вопрос о Совете останется подвешенным, и после заседания движение обратится к мэру за помощью в договоренности с администрацией ${ }^{8}$.

Здесь важно отметить, что сама городская администрация на этом этапе была не столь монолитна, как могло показаться в ранние периоды. Для движения мэр был человеком с политической волей: вопреки ограничениям законодательных актов и нежеланию чиновников, он мог продвинуть какое-то решение (например, отказаться от бюджетных денег в пользу сохранения брусчатого покрытия). Поэтому оно несколько раз обращалось к мэру, чтобы он повлиял на своих подчиненных. На этом этапе городская администрация «раскалывается» на три лагеря: первый - это мэр, у которого есть политическая воля, второй - это крупные чиновники, обычно его заместители, на которых легла основная работа по утверждению договоренностей с активистами, и третий - остальные чиновники, которые просто делали то, что им говорили. Последние, как отмечалось в интервью, осуществляли «максимальное перекладывание ответственности с себя на вот этого человека <мэра>» и не имели прав голоса [Инф. A].

На той же встрече движение в нескольких аспектах изменило свой курс действий. Во-первых, участники «Спасем брусчатку!» стали апеллировать к нормативным актам, а не просто к общественному мнению. Они указали на то, что в 2001 году прежней администрацией были проведены исследования, которые показали, что с брусчаткой городская среда более эконо-

8 Необходимость в другом Совете была связана с тем, что, по мнению участников движения, с заместителем мэра невозможно договориться и уладить спор о брусчатке. 
мичная и эстетичная. Апелляция к нормативным актам была связана отчасти с тем, что активность проявили архитекторы, а отчасти - с тем, что чиновники хорошо понимали язык нормативных актов, а не красивые метафоры. Во-вторых, основной упор в обсуждении был сделан на то, как происходит заказ строительных работ, как контролируется его выполнение, куда направляется и где хранится брусчатка. То есть от первоначальных разговоров об историческом наследии в тот момент отказались. Согласно комментарию одной из участниц, хотя внутри группы они говорили и писали про брусчатку как культурное наследие и даже были предложены такие метафоры брусчатки, как «кожа города» или «машина времения», в коммуникации с чиновниками они такими метафорами не пользовались. «Я не могу себе представить, - говорит она, - что мы придем к мэру или к начальнику по дорожным работам и будем им про кожу говорить. Потому что он нам скажет: “У меня там письма <от недовольных жителей> говорят, что нужно снять брусчатку”» [Инф. А.].

Иначе говоря, на этом этапе произошло изменение дискурса движения в споре. Отстаивая культурную ценность брусчатки, общество в своем дискурсе начало реагировать на аргументы городской администрации, что брусчатка - это, может, и историческая ценность, но она неудобна для современного города. Аргумент движения теперь состоял в том, что брусчатка была бы удобной, если бы городская администрация научилась ее перекладывать. После встреч с движением отменяются многие решения по асфальтированию улиц Калининграда в 2012 году.

Казалось, что спор начинал потихоньку разрешаться: мэр прислушивался к движению и администрация переставала снимать брусчатку. Аргументы о том, что брусчатка - это дорого, долго, шумно и непрочно, как будто уступили аргументам о том, что ее надо сохранять, поскольку это культурная достопримечательность Калининграда и поскольку, главное, так считают многие жители города и избиратели.

Однако лето 2012 года показало, что спор еще не закончился. В июне прошла еще одна встреча с мэром города и его заместителями. На этой встрече активисты движения предложили на уровне города признать, что брусчатка - это историческое наследие и нужно сохранять ее везде, где это возможно. Они предлагали зафиксировать это в специальном регламенте, который имел бы обязательный характер для всех чиновников города. Однако заместитель мэра по строительству был с этим не согласен. Он указал, что ремонт дорог и демонтаж брусчатки финансируются по федеральной программе. Если признать брусчатку наследием, надо отказываться от ремонта, но тогда город потеряет много денег. Кроме того, он настаивал, что жители все же недовольны самой брусчаткой как покрытием. Активисты обвинили чиновников в том, что те просто хотят получить как можно больше денег, не заботясь о городе, и указали на то, что намечен ремонт нескольких улиц, находившихся в отличном состоянии.

На этой встрече мэр опять встал на сторону защитников брусчатки. Он отметил, что брусчатку в целом будут в городе сохранять и что администрация создаст специальную группу, которая обсудит регламент по сохранению брусчатки в Калининграде.

Как мы видим, мэр уже на второй встрече поддерживал не своих заместителей с их аргументами о потере финансов и строительных проблемах, а гражданскую инициативу. Причем это делалось как в отношении демонтажа брусчатки, так и в отношении принятия регламента, то есть изменения нормативной документации.

Еще одной важной мини-победой движения в этот период было то, что участники движения посетили склад (бывшее трамвайное депо), где хранилась снятая брусчатка. Оказалось, что большая часть снятой брусчатки находится не у государства, а у частных строительных фирм, которые асфальтируют улицы и снятые камни хранят у себя. Как пояснил директор этого склада, еще четыре года назад (то есть в 2008 году) брусчатка считалась просто строительным бутом, который используют как сопутствующий материал, не заботясь о нем. Еще недавно брусчатка никого не волновала, а теперь администрация обещает бережно хранить ее на специальных складах. Что, как не это, является подтверждением того, что брусчатка обрела статус историко-культурного наследия, правда пока только в публичном дискурсе?

Таким образом, разворачивание спора состояло в том, что общественное движение переключилось с дихотомии «сохранять или не сохранять» на критику работы городской админи-

9 В том смысле, что она переносит пешеходов буквально физически в другое, старинное, пространство: см. схожий аргумент в [Димке, Руденко, 2017]. 
страции с брусчаткой, а также на создание нормативного регламента работы с брусчаткой. Успех и в том, и в другом направлении мог бы закрепить роль гражданской экспертизы в работе с городским пространством и сделать брусчатку культурной ценностью не только в публичном дискурсе, но и в нормативных документах. Однако, как покажет следующий, заключительный этап, этого не произошло.

\section{Пятый этап. Закрытие спора}

Прагматическая социология рассматривает силу и слабость акторов как относительные сущности: никто не может быть силен или слаб от природы, но вынужден опираться на ресурсы, позволяющие быть сильным или лишающие силы. Когда движение «Спасем брусчатку!» стало выдвигать аргументы относительно нормативного регламента и фокусировать внимание на том, как городские власти работают с брусчаткой, оно вступило в противостояние с такими элементами выстроенной городской властью сети, которые оказались более прочными и которые инициативная группа не смогла мобилизовать в свою пользу.

Прежде всего, движение не смогло подтвердить свои обвинения, что городская администрация и компании, занимающиеся переукладкой брусчатки в Калининграде, работают с камнем некомпетентно. Здесь стоит привести случай с инспекцией перекладывания брусчатки на улице Тельмана в июле 2012 года. Тельмана - старая и одна из самых известных улиц Калининграда, названная в честь немецкого коммуниста Эрнста Тельмана, погибшего в Бухенвальде. Она выложена брусчаткой и идет мимо элитных особняков; рядом - Верхнее озеро, одно из главных мест отдыха жителей города. Брусчатка на Тельмана примечательна тем, что в полной мере воплощает в себе и артикулирует аргументы участников спора. С одной стороны, она вписывается в исторической антураж, сама по себе очень эстетична и красиво выложена «павлиньим пером». С другой стороны, Тельмана - это улица с интенсивным движением, ею часто пользуются те, кто едет из центра города на север и северо-восток. Здесь большой поток машин и состояние брусчатки кое-где не очень хорошее. Городские чиновники часто ссылались на этот факт, говоря о том, что брусчатка не выдерживает интенсивности движения и ее нужно убрать. Но движение за спасение брусчатки на это отвечало, что проблема не в самой брусчатке, а в том, что ее не умеют перекладывать. Именно с этим были связаны вопросы на одной из встреч в июле 2012 года: кто и как контролирует укладку брусчатки? Возможно, вина в плохом состоянии брусчатки на городской администрации, которая не умеет контролировать качество ее укладки? Чтобы проверить и подтвердить это, в июле 2012 года инициативная группа, мэр и заместители мэра отправились на Тельмана, чтобы на месте оценить качество работ.

На встрече участники движения раскритиковали способ укладки брусчатки, отметив среди прочего, что расстояние между камнями шире, чем нужно, камни большего размера, чем указано в нормах, траектория укладки не соответствует технологии и различается от места к месту и т.д. [Новожилова, 2012]. По сути, здесь выдвигается обвинение как дорожной компании-укладчику, так и чиновникам. От компании на встрече присутствовал главный инженер, он был недоволен комментариями и заявил в ответ, что работы еще не закончены, что технологии укладки применяются к калиброванному (то есть имеющему одну и ту же высоту и ширину) камню, а они работают с некалиброванным камнем, что дорогу еще не трамбовали и т.д. В свою очередь, заместитель мэра отверг все обвинения активистов, сказав, что дорожная компания не вела полноценный ремонт камня, а лишь «приводила дорожное покрытие к нужной геометрии» [Там же].

Этот случай весьма показателен с точки зрения прагматической социологии. Эта социология внимательна к проверкам слов и квалификаций, которые даются людям и объектам. Вспомним, что чиновники и сам мэр в разных спорах с 2010 года указывали на то, что брусчатка - менее прочное покрытие. Защитники брусчатки на встречах в начале 2012 года раскритиковали этот взгляд, заменив его двумя другими квалификациями: это не брусчатка не прочна, это а) дорожные компании не умеют ее перекладывать, б) администрация города не умеет следить за качеством укладки. Они выехали на место, чтобы доказать это. И оказалось, что они правы: технология не соблюдалась. Однако им было отказано в этой критике под предлогом незаконченности работы. Вдобавок их квалификации подверглись критике со стороны самих чиновников, потому что, как оказалось, есть разные типы работ с дорож- 
ным покрытием: одна - полноценный ремонт, другая - «приведение дорожного покрытия к нужной геометрии». Фактически это означало, что городская администрация сознательно опиралась на позицию не производить полноценного (а значит, технологически верного) ремонта улицы и ее можно было обвинить в том, что она сама же и создавала брусчатку низкой прочности.

После проверки брусчатки на Тельмана движение пишет письмо мэру, обвиняя чиновников в том, что они сами создают основания для плохого ремонта улиц с брусчаткой. Однако в этот, третий, раз мэр (впервые) их не поддерживает. Он защищает позиции дорожной компании и чиновников. Так, в ответном письме он отмечает: «Сертифицированной лабораторией ООО «Калининградстройхолдинг» 24 июля 2012 г. <...> были проведены контрольные замеры коэффициента уплотнения основания, межплиточной засыпки и подстилающего песчаного слоя. Расхождений с требованиями... СНИП не отмечено» ${ }^{10}$. Отсылка к лаборатории очень примечательна. Тем самым отклоняются любые аргументы с замерами расстояний между камнями, которые инициативная группа делала «на глазок». Привлечение науки в качестве союзника это сильный ход, позволяющий отвергнуть почти любые обвинения. На это движение могло мало что ответить.

Вторым фактором проигрыша движения была его попытка написать и принять регламент обращения с брусчатым камнем в городе. Эта попытка была предпринята осенью 2012 года. Общая идея регламента состояла в том, что брусчатое покрытие априори признается исторической ценностью и в случае его снятия городская администрация должна предъявить причины и доказать, что такое снятие необходимо. Помимо этого, предлагалось разработать проект муниципального технического стандарта работ с брусчатым камнем и разработать программу возвращения демонтированного камня обратно в эксплуатацию. Этот регламент преследовал цель, заявленную движением еще в открытом письме в начале года: создать стратегию работы с брусчаткой на городском уровне.

В ноябре 2012 года этот грандиозный документ отправляется в городскую администрацию. В сентябре-октябре проходят выборы мэра, и 1 ноября мэр переизбирается на очередной срок. В январе 2013 года группа проводит городской «день брусчатки», куда приглашает всех желающих, включая мэра.

В феврале 2013 года группа получает от одного из заместителей мэра «замечания (протокол разногласий)», где заместитель во всех подробностях описывает, почему регламент, предлагаемый движением, не может быть воплощен. Этот документ очень любопытен именно в свете того, что он ставит точку в споре между чиновниками и движением «Спасем брусчатку!». Почти каждый пункт проекта регламента был разобран и сопровождался обоснованием, почему он не может быть реализован. К примеру, технический регламент не может быть создан на муниципальном уровне, это прерогатива только федерального закона или указа президента. Брусчатый камень является строительным материалом и не связан с целью сохранения историко-архитектурного облика города. Поэтому нет оснований для его безусловного сохранения. Нет никакого финансирования для разработки программ возвращения камня и других заседаний и обсуждений. Проведение обследований брусчатого камня, чтобы обосновать его демонтаж, также не подкреплено ни финансовыми ресурсами, ни лабораторными мощностями. В регламенте недостаточно данных по тому, куда и как транспортируется камень.

Этот ответ указывает на то, что у движения «Спасем брусчатку!» слишком мало союзников, чтобы продвинуть такой регламент. У них нет ресурсов для изменения федерального технического регламента. Они не могут доказать нормативность утверждения, что брусчатка - часть исторического наследия. У движения нет финансирования и лабораторных мощностей для проведения обследования камня. В конце письма предлагается сохранять брусчатку лишь как часть исторических памятников. По сути, это возвращает движение к самому началу спора, к январю 2012 года, когда оно только зародилось.

Техническая несостоятельность аргументов движения делается видимой и в ходе следующего действия администрации. Она обращается к городским экспертам с вопросом: стоит ли сохранять брусчатку? Так, в начале марта 2013 года в горадминистрации проходит круглый стол, посвященный состоянию улиц Калининграда. На нем не присутствуют представители

10 Этот и другие документы в открытом доступе можно найти здесь: https:/www.facebook.com/groups/gorodk/files/*. 
движения «Спасем брусчатку!», зато присутствуют строители, инженеры, доктора технических наук, заместители мэра, компании, которые ремонтируют дороги, сотрудники ГИБДД. На повестке разные дорожные вопросы, но центральный из них - брусчатка. Говоря о ней, один из ученых отмечает, что на больших улицах вроде Тельмана из-за интенсивности движения брусчатка будет постоянно «плыть», и приводит данные по ГОСТу: брусчатка должна находиться на улицах, где интенсивность движения не более 2000 машин в сутки (на Тельмана 6000). Впрочем, в то же время он отмечает, что на улицах города в некоторых местах брусчатка лежит вполне сносно, потому что сделана по технологии.

Мэр использует этот аргумент и в эфире одной из передач говорит, что снятие брусчатки с улиц санкционировано экспертами. Через несколько дней Окружной совет депутатов постановляет убрать брусчатку с Парковой аллеи, с которой все и началось в 2010 году. Но, видимо, чтобы на всякий случай заручиться поддержкой людей, администрация проводит еще одно интернет-голосование о том, оставлять ли брусчатку на Парковой аллее.

Это действие мэра демонстрирует, что между диспозитивом технической экспертизы и нормативных актов и диспозитивом публичной информации нет четкого перехода. Изменение позиции мэра вызывает неоднозначную реакцию в СМИ. Ученый-строитель - тот самый, который выступал на круглом столе, - пишет в издании «Дворник» статью с критикой решения мэра [Савкин, 2013]. Он отмечает, что в Калининграде есть и негативные, и позитивные примеры восстановления брусчатки и что высказывание мэра о необходимости асфальтировать Тельмана и другие улицы «никаких оснований, кроме эмоциональных» не имеет. В «Комсомольской правде» выходит статья, в которой утверждается, что городская администрация не умеет работать с общественностью, а мэр упрекается в том, что использовал движение «Спасем брусчатку!» в своих «стратегических целях», а именно чтобы выиграть выборы [Денисенков, 2013]. Помимо этого отмечается, что перекладывать брусчатку никто в Калининграде не только не умеет, но и учиться не хочет. Иначе говоря, повторяются аргументы движения «Спасем брусчатку!».

В связи с новым поворотом движение постаралось опереться на диспозитив, который помог ему добиться расположения мэра год назад. Они помогают активистке с улицы Парковая аллея написать письма с просьбой о помощи губернатору Калининградской области, в Государственную думу и полномочному представителю Президента Российской Федерации в Северо-Западном федеральному округе. Срабатывает последнее письмо, и в конце марта мэр, полномочный представитель и участники движения встречаются и договариваются, что брусчатку с Тельмана и Пролетарской улицы снимать не будут. При этом решение по Парковой аллее после этих переговоров осталось прежним, и уже осенью, когда начинаются работы по демонтажу брусчатки, жители пытаются писать очередные открытые письма.

Неудачи в защите брусчатки и перемена позиции мэра приводят к напряжению в самом движении. Одна из участниц отмечает, что в феврале 2013 года группа разделилась: одни считали, что нужно продолжать «обрабатывать власть» и общаться с ее представителями, другие - что это бессмысленно, потому что власть просто воспользовалась ими; наконец, третьи говорили о необходимости «партизанить» (то есть выступать против демонтажа при помощи каких-то неформальных средств). В итоге «похорон группы не было, как-то вот затихло, перестали действия предпринимать» [Инф. Л].

\section{Шестой этап. Последствия спора}

Группа перестала существовать как активная сила, регламент по защите брусчатки был отозван, а раскритиковать некомпетентность администрации и строительных компаний по работе с камнем не удалось. Однако, несмотря на все это, можно говорить о том, что деятельность движения привела к значительным последствиям в жизни города. Во-первых, в публичном дискурсе было сконструировано представление о брусчатке как историческом наследии. К нему до сих обращаются, например, СМИ и сами власти. Во-вторых, это было первое в истории города гражданское движение в защиту города. Даже после всех событий с брусчаткой мэр ссылается на это движение, а некоторых участников движения зовут на заседания и публичные встречи, связанные с развитием города. Сами активисты принимали и принимают сегодня участие в защите других элементов городской среды: аллей, городской зелени, старинных мостов и т.д. В-третьих, участники отмечают, что городские чиновники научились разговари- 
вать с городскими движениями. Так, одна из участниц говорит про заместителя мэра, с которым они работали: «Во время брусчатки он был просто таким технократом, молодым чиновником, который, в принципе, только ссылался на какие-то регламенты и юридическое поле, в общем-то, ничего не понимал и не желал разговаривать ни с кем... <а теперь> он предпочитает не ссориться, максимально настроен на диалог, идет на встречи, куда его зовут, говорит, что ничего невозможного нет» [Инф. А].

\section{Калининградский кейс в свете прагматической социологии}

Вернемся к трем различениям, которые стали камнем преткновения между прагматической социологией и более традиционными городскими исследованиями. После того, как был описан кейс калининградской брусчатки, хочется еще прояснить то, как прагматическая социология может помочь нам улучшить наше понимание процессов оспаривания города.

Сильные и слабые акторы

В то время как критическая социология города видит силу и слабость как некоторую данность, неравномерно распределяя их между акторами, прагматическая социология стремится увидеть силу (например, в виде власти) как практическое достижение или опору на набор устоявшихся сильных союзников.

В случае брусчатки движение изначально было слабым. По сути, участвовавшие в нем люди не отличались от анонимных голосов на форуме городской администрации. Но они становятся сильными, когда привлекают более 476 подписей под своим письмом (включая директоров музеев и редакторов местных газет), когда они становятся представителями недовольных жителей улиц, с которых снимают брусчатку, когда они обвиняют власти в отсутствии продуманной политики в отношении исторического наследия Восточной Пруссии. Их сила проявляется, когда мэр решает пригласить их на встречу и идет им на уступки, несмотря на недовольство своих заместителей и потерю федеральных денег. Когда чиновники на встречах в администрации отчитываются перед ними о том, как создаются технические задания и контролируется работа дорожных компаний. Когда главный инженер одной такой дорожной компании вынужден оправдываться за то, что между камнями слишком широкий зазор или что они неправильно уложены. Их сила подкрепляется знанием о том, что делают в соседних городах, новостями СМИ, которые дают им место для выражения своей критики, мнением архитекторов, которые почти полностью признают важность брусчатки для города.

Однако они начинают терять силу там, где пытаются оспорить существующее положение вещей в техническом и нормативном аспекте. У них нет доступа к инженерным лабораториям и нет денег, чтобы сделать собственное обследование расстояния между камнями брусчатки. Также у них нет инженеров-строителей, которые могли бы экспертно заявить публике, что брусчатку нужно сохранять на улицах. Против них - правовые акты, которые не допускают изменения технологии работы с брусчаткой на местном уровне и не признают брусчатку элементом культурного наследия. Несомненно, у них была возможность сделать себя еще сильнее: если бы они заинтересовали службу охраны памятников, если бы они нашли инвестора, если бы у них был лоббист на федеральном уровне. Но, как показывает «протокол разногласий», таких союзников у них не нашлось, а вместе с тем не нашлось и оснований для реализации своей критики.

В то же самое время сильные акторы, прежде всего чиновники и крупный бизнес (те же дорожные компании), совсем не похожи на априори сильных акторов. Для переизбрания на выборах мэр вынужден договариваться с общественными организациями. Его заместители вынуждены терпеть диалог с движением и критику от него вплоть до обвинений в том, что городские власти не умеют работать с дорожными компаниями, которые делают некачественную работу. Описанная нами ситуация вокруг улицы Тельмана говорит о том, что мэр - а с ним в данном случае и вся городская администрация - сильны не сами по себе: они опираются на нормативные стандарты, научные лаборатории и экспертов. Такую сильную сеть не в силах преодолеть инициативное движение, среди союзников которого нет ни инженеров, ни чиновников.

Таким образом, сила и слабость - это практические достижения, которые опосредованы опорой на устойчивых союзников. Как показывает кейс брусчатки, сети союзников городской 
администрации оказались сильнее, чем сети союзников движения, по крайней мере в заключительной части истории.

\section{Машины роста и места памяти}

Выше, в теоретическом параграфе, мы показали, что для некоторых исследователей города (в частности, Сеты Лоу) важное значение имеет различение «социального производства» и «социального конструирования» городского пространства. Первая часть различения предполагает материальный аспект изменения города (то есть работу с городской инфраструктурой, застройкой и т.д.), вторая - работу с символическим (памятью, дискурсивностью). Согласно Лоу, городские власти занимаются первым, в то время как жители и городские активисты в основном вторым. В кейсе калининградской брусчатки мы показали, что в процессе спора инициативное движение было способно влиять и на конструирование, и на производство пространства.

Отталкиваясь от идеи, что брусчатка - это культурное наследие, активисты выступают за изменение конкретной работы с ней, то есть здесь пересекаются между собой материальное производство пространства и символическое конструирование. Движение выступает за производство городского пространства, потому что именно оно предоставляет возможность сохранить исторические камни на улицах города. Благодаря движению камни оставляют на нескольких улицах города, где их планировали убрать. Вместо хранения на складах частных строительных компаний брусчатку начинают складировать в городском трамвайном депо. Далее активисты посещают улицу Тельмана, чтобы проверить расстояние между камнями, и предлагают введение нового технического регламента для работы с камнями.

Помимо этой работы движение сосредотачивает свое внимание на формировании представления о калининградской брусчатке как об историко-культурном наследии, как о символе региона, как о туристической достопримечательности Калининграда, о том, что делает городскую среду более комфортной и «человекоразмерной». Когда в 2016 году социологи из другого проекта будут исследовать представления горожан о том, что такое хорошая городская среда, то брусчатка будет появляться в интервью очень часто ${ }^{11}$.

В итоге мы видим, что городское движение во время спора одинаково удачно могло объединять социальное производство и социальное конструирование городского пространства. Априорное различение того и другого кажется ошибочным. Машины роста и места памяти являются для самих акторов практическими достижениями в ходе спора.

Люди и вещи

История с брусчаткой показывает эвристичность подхода объектно-ориентированной политики [Marres, 2007]. Это подход, который демонстрирует, что вещи и их способность к сопротивлению играют активную роль в политике, что люди часто спорят именно по поводу вещей или привлекают их в качестве союзников.

Движение «Спасем брусчатку!» появляется на волне все большей озабоченностей жителей Калининграда ситуацией с брусчаткой. Оно направляет неудовлетворенность разрушением брусчатых улиц и исторических зданий в целом в единую гражданскую инициативу. Когда движение находит временную договоренность с мэром, брусчатку перестают снимать с отдельных улиц. В публичном дискурсе постепенно закрепляется ее статус как культурного наследия, что, в свою очередь, приводит к необходимости иначе с ней обращаться и, прежде всего, научиться работать с ней. Движение пытается критиковать существующие практики городской администрации, как работать с брусчаткой: оно пытается понять, как составляется техзадание на работу с брусчаткой, как контролируются работы и т.д. Движение даже выезжает на одну из главных улиц, по поводу которых идет спор, - на улицу Тельмана, чтобы с помощью линейки и глаза проверить, насколько точно соблюдаются технологии укладки. Однако их критика и обвинение, которые могли бы привести не просто к сохранению брусчатки, а к изменению практик работы с ней и, следовательно, к возможности поддерживать ее в хорошем состоянии в будущем, не срабатывают. Администрация и мэр, опираясь на пока-

11 Личная коммуникация с руководителем проекта О. Сезневой. 
зания экспертов из дорожных лабораторий, оправдывают существующую технологию работы с брусчаткой тем, что камень не калиброванный и что речь не идет о полноценном ремонте. То есть выстроенный администрацией диспозитив нормативных документов и союзников от науки выдерживает натиск критики, обвиняя, в свою очередь, самих участников движения в том, что у тех нет никаких оснований для выдвижения полноценной критики: нет лаборатории, нет нормативных актов, нет экспертов. Кроме того, брусчатке так и не придали статус культурного наследия: оказалось, что его просто невозможно придать дорожному покрытию, пусть даже его положили 100 лет назад и «павлиньим пером». В итоге нормативный и административный диспозитивы ограничивают возможности критики движения. И мэр города, сославшись на экспертный круглый стол, способен изменить свое решение и начать убирать брусчатку, потому что ему ничего за это не грозит. Тендеры на замену брусчатки асфальтом опять начинают разыгрывать, а движение, поняв невозможность выиграть в этом административном поле, постепенно исчезает, оставаясь виртуально активным только в публичном дискурсивном поле.

Эта история показывает, что роль вещей в политике не так однозначна, чтобы видеть в них только объекты социального конструирования. Во-первых, вещи собирают людей вокруг себя: так брусчатка собрала вокруг себя защитников исторического наследия. Хотя камни и не обладали собственной агентностью, однако комментарии жителей на страницах газет и на форуме показывают, насколько камни были эстетически и практически приятны и комфортны для горожан - до такой степени, что люди были готовы лично противостоять строительной технике. Постепенно из этого выросло целое городское движение, включающее людей, порой не очень близких друг другу в реальной жизни, но объединенных общим желанием сохранить старинные камни на улицах.

Во-вторых, вещи сопротивляются нарративам агентов и могут выступать «союзниками» в борьбе за отстаивание той или иной версии реальности. В случае брусчатки это вылилось в то, что она становилась частью исторического Калининграда. Чтобы убедить жителей поддержать протест, движению достаточно было призвать их представить город, закатанный в асфальт. Туристический Калининград невозможно представить без брусчатки, что также отмечали городские активисты. «Спасем брусчатку!» как бы говорило: «Если вы хотите туристический Калининград, то вы должны сохранить брусчатку на улицах городах. Нет брусчатки - нет туристов!».

В той же мере замеры расстояния между камнями, совершаемые активистами, касались того, чтобы доказать: городская администрация и строительные компании некомпетентны в работе с камнем. Как мы видели, этот замер показал правоту движения, но он не повлиял на их силу, поскольку городская администрация имела инженерную лабораторию, чье мнение было более авторитетным, чем мнение активиста с линейкой. И тем не менее именно привлечение самих камней позволило выдвинуть критику в некомпетентности.

Таким образом, еще одно различение - между людьми и вещами - может быть проблематизировано, если мы говорим о ситуации спора, где доказательство своей правоты опирается на состояние вещей не в меньшей мере, чем на людей.

\section{Заключение}

В данной статье были продемонстрированы возможности применения прагматической социологии к случаю городского спора в России. Был рассмотрен спор между движением «Спасем брусчатку!» и администрацией Калининграда по поводу того, необходимо ли снимать историческое брусчатое покрытие в городе. Было показано, что в анализе подобных споров нельзя начинать с разделения акторов на сильных и слабых: сила и слабость акторов являются практическим результатом их деятельности по заинтересовыванию своих сторонников, а также спора, в котором они участвуют. Также было подвергнуто критике различение «социальное производство - социальное конструирование» городского пространства, поскольку, как было показано, символические и прагматические элементы зачастую бывают перетасованы в споре. Наконец, было показано, что роль вещей в городских спорах, особенно если спорят по поводу них, выходит далеко за пределы только объектов социального конструирования. Целью статьи было в том числе привлечь внимание к эмпирическому измерению самой ситуации спора по поводу городского пространства, - спора, в рамках которого акторы чаще всего обнажают 
невидимые до того системы отношений. Вместо рассказывания историй про четкий набор агентов любого городского противостояния, вероятно, порой полезно быть более чувствительным к тому, какие внезапные союзы возникают и исчезают.

\section{Список информантов}

Инф. А. - женщина, участница движения, социальный исследователь, преподаватель.

Инф. О. - женщина, участница движения, искусствовед, историк.

Инф. Л. - женщина, участница движения, социальный исследователь, преподаватель.

Инф.И. - мужчина, краевед.

Инф. Т. - мужчина, инженер.

\section{Источники}

Барт Я. и др. (2019) Прагматическая социология: инструкция по применению//Социология власти. Т. 31. № 2. С. $176-216$.

Болтански Л., Тевено Л. (2013) Критика и обоснование справедливости: Очерки социологии градов/Пер. с франц. О.В. Ковеневой под науч. ред. Н.Е. Копосова. М.: Новое литературное обозрение.

Власти предлагают «раз и навсегда» определить, где оставлять брусчатку (2011)//Новый Калининград. Режим доступа: https://www.newkaliningrad.ru/special/roadholes/1287534-vlasti-predlagayut-raz-i-navsegdaopredelit-gde-ostavlyat-bruschatku.html (дата обращения: 18.05.2020).

Гладарев Б. (2012) Градозащитные движения Петербурга накануне «зимней революции» 2011-2012 гг:: анализ из перспективы французской прагматической социологии//Мониторинг общественного мнения: экономические и социальные перемены. Т. 110. № 4. С. 29-43

Денисенков А. (2013) Как асфальт Калининграда победил брусчатку Кенигсберга//Комсомольская правда. Калининград. Режим доступа: https://www.kaliningrad.kp.ru/daily/26049.4/2961767/ (дата обращения: 18.05.2020).

Димке Д.В., Руденко Н.И. (2017) Когда история дает сдачи: городские пространства и память вещей //Этнографическое обозрение. № 6. С. 14-29.

Каллон М. (2015) Некоторые элементы социологии перевода: одомашнивание морских гребешков и рыбаков залива Сен-Бриё//Социология власти. Т. 27. № 1. С. 196-231.

«Комсомолка» начинает акцию «Спасем брусчатку старого города!» (2010)//Комсомольская правда. Калининград. Режим доступа: https://www.kaliningrad.kp.ru/daily/24587/756920/ (дата обращения: 18.05.2020).

Латур Б. (2002) Дайте мне лабораторию, и я переверну мир//Логос. Т. 35. № 5-6. С. 1-32.

Новожилова Т. (2012) «На брусчатке под дождем»: репортаж «Нового Калининграда.Ru» с улицы Тельмана//Комсомольская правда. Калининград. Режим доступа: https://www.newkaliningrad.ru/news/community/ 1642687-na-bruschatke-pod-dozhdem-reportazh-novogo-kaliningradaru-s-ulitsy-telmana.html (дата обращения: 18.05.2020).

Обращение о статусе брусчатого покрытия как элемента историко-культурного наследия Калининградской области (2012). Режим доступа: https://docs.google.com/forms/d/e/1FAlpQLSdVJOjqsh_XsGw-aUW4KyhAkClin qJSVY7CHKoG7LDSPpfpgw/viewform?formkey=dHcOblhQMjBmLTBqOE9Rc2FXN3BvZFE6MQ (дата обращения: 18.05.2020).

Опросы (2020)//Горадминистрация Калининграда. Режим доступа: https://www.klgd.ru/vote/index.php (дата обращения: 18.05.2020).

Про брусчатку//Livejournal. Режим доступа: https://yaroshuk.livejournal.com/?skip=10 (дата обращения: 18.05.2020).

Савкин Г. Брусчатка насмарку? (2013)//Издание «Дворник». Режим доступа: http://www.dvornik.ru/issue/868/ 28922/?sphrase_id=230534 (дата обращения: 18.05.2020).

Составим список улиц, где сохранилась брусчатка (2011)//Издание «Клопс». Режим доступа: https://klops.ru/ news/obschestvo/34228-sostavim-spisok-ulits-gde-sohranilas-bruschatka (дата обращения: 18.05.2020).

Тыканова Е.В. (2013) Стратегии и тактики оспаривания городского пространства группами интересов (на примере конфликтов вокруг городского развития в Санкт-Петербурге)//Вестник Санкт-Петербургского университета. Серия 12. Социология. Вып. 1. С. 103-110.

Форум (2020)//Горадминистрация Калининграда. Режим доступа: https://www.klgd.ru/reception/forum/index. php?PAGE_NAME=read\&FID=33\&TID=212\&PAGEN_1=18 (дата обращения: 18.05 .2020 ). 
Bénatouil T.A. (1999) Tale of Two Sociologies: The Critical and the Pragmatic Stance in Contemporary French Sociology//European Journal of Social Theory. Vol. 2. No. 3. P. 379-396.

Breviglieri M., Stavo-Debauge J. (1999) Le Geste Pragmatique de la Sociologie Française. Autour des Travaux de Luc Boltanski et Laurent Thévenot//Antropolítica. Vol. 7. P. 7-22.

Lemieux C. (2018) La Sociologie Pragmatique. Paris: La Découverte.

Low S.M. (2000) On the Plaza: the Politics of Public Space and Culture. Austin: University of Texas Press.

Marres N. (2007) The Issues Deserve More Credit: Pragmatist Contributions to the Study of Public Involvement in Controversy//Social Studies of Science. Vol. 37. No. 5. P. 759-780.

Thévenot L. (2006) L'action au pluriel. Sociologie des regimes d’engagement. Paris: La Découverte.

Tykanova E., Khokhlova A. (2015) The Performative Logic of Urban Space Contestation: Two Examples of Local Community Mobilisation in St. Petersburg//Urban Grassroots Movements in Central and Eastern Europe/ K. Jacobsson (ed.). Abingdon: Ashgate. P. 139-162.

Tykanova E., Khokhlova A. (2019) Grassroots Urban Protests in St. Petersburg: (Non)Participation in Decision-Making on the Futures of City Territories//International Journal of Politics, Culture and Society. Vol. 33. P. 1-22.

Williams R. (1983) Culture and society, 1780-1950. Columbia University Press.

*Социальные сети Instagram и Facebook запрещены на территории Российской Федерации. 21.03.2022 компания Meta признана экстремистской организацией. 
NIKOLAY RUDENKO

FROM OBLIVION TO THE STUMBLING ROCKS AND BACK

\title{
A PRAGMATIC SOCIOLOGICAL ANALYSIS OF THE CONTROVERSIES AROUND KALININGRAD COBBLESTONES
}

Nikolay I. Rudenko, PhD in Sociology, Researcher at the Center for Research in Science and Technology of the European University at St. Petersburg; Affiliated Fellow of the Sociological Institute of the Russian Academy of Sciences (branch of the FCTIS RAS); letter A, 6/1 Gagarinskaya Street, St. Petersburg, 191187, Russian Federation.

E-mail: diogenstyx@gmail.com

\begin{abstract}
This article deals with the description and analysis of the controversy in 2010-2013 around the historic cobblestones in Kaliningrad when there was massive asphalting of streets, replacing German paving stones. This caused discontent and protests from citizens, leading to the emergence of the city's first civil activist movement ("Save the cobblestones!") to protect the city and its historical heritage. The article describes the appearance of this movement, its dynamics and the reasons for its disappearance. The French tradition of pragmatic sociology is used as a theoretical framework. The article focuses on how the controversy unfolded around the questions of whether to keep or remove the historical paving stones from the streets of the city, what resources each side used (the city administration and the activist movement), what regulatory, institutional and political restrictions were possible to narrow the possibility of criticism of the actions of the city administration. The article is based on the case study method, during which 10 interviews were collected with participants in the movements, journalists, architects, engineers, etc. Local periodicals, and posts and documents from online activists were collected and analyzed. The article shows that criticism of the actions of the authorities became possible thanks to the media, social networks, appeals to officials, but it was limited by normative documents and administrative obstacles.
\end{abstract}

Keywords: civic urban activism; pragmatic sociology; cobblestones; Kaliningrad

Citation: Rudenko N. (2020) From Oblivion to the Stumbling Rocks and Back: A Pragmatic Sociological Analysis of the Controversies Around Kaliningrad Cobblestones. Urban Studies and Practices, vol. 5, no 2, pp. 50-70 (in Russian) DOI: https://doi.org/10.17323/usp52202050-70

\section{References}

Bart Y. et al (2019) Pragmaticheskaja sociologija: instrukcija po primeneniju [Pragmatic sociology: the guide]. Sociologija vlasti [Sociology of Power], vol. 31, no 2, pp. 176-216. (in Russian)

Bénatouil T.A. (1999) Tale of Two Sociologies: The Critical and the Pragmatic Stance in Contemporary French Sociology. European Journal of Social Theory, vol. 2, no 3, pp. 379-396.

Breviglieri M., Stavo-Debauge J. (1999) Le Geste Pragmatique de la Sociologie Française. Autour des Travaux de Luc Boltanski et Laurent Thévenot. Antropolítica, vol. 7, pp. 7-22.

Boltanski L., Thévenot L. (2013) Kritika i obosnovanie spravedlivosti: Ocherki sociologii gradov [On Justification: Economies of Worth]/Translation of O.V. Kovenevoj, N.E. Koposova (ed.). Moscow: Novoe literaturnoe obozrenie [New Literary Review].

Denisenkov A. (2013) Kak asfal't Kaliningrada pobedil bruschatku Kenigsberga [How the asphalt won the cobblestones]. Komsomol'skaja Pravda. Kaliningrad [Komsomolskaya Pravda. Kaliningrad]. Available at: https:// www.kaliningrad.kp.ru/daily/26049.4/2961767/ (accessed 18 May 2020). (in Russian)

Dimke D.V., Rudenko N.I. (2017) Kogda istorija daet sdachi: gorodskie prostranstva i pamjat' veshhej [When the history strikes back: urban spaces and the memory of things]. Jetnograficheskoe obozrenie [Etnograficheskoe obozrenie], no 6,pp. 14-29. (in Russian)

Forum. Goradministracija Kaliningrada. Available at: https://www.klgd.ru/reception/forum/index.php?PAGE_NAME=r ead\&FID=33\&TID=212\&PAGEN_1=18 (accessed 18 May 2020). (in Russian) 
Gladarev B. (2012) Gradozashhitnye dvizhenija Peterburga nakanune «zimnej revoljucii» $2011-2012$ gg.: analiz iz perspektivy francuzskoj pragmaticheskoj sociologii [City protection Movements of St. Petersburg on the Eve of the «Winter Revolution» 2011-2012: Analysis from the Perspective of French Pragmatic Sociology]. Monitoring obshhestvennogo mnenija: jekonomicheskie i social'nye peremeny [HYPERLINK «https://www.monitoringjournal. ru/index.php/index» Monitoring of Public Opinion: Economic and Social Changes Journal], vol. 110, no 4, pp. 29-43. (in Russian)

Kallon M. (2015) Nekotorye jelementy sociologii perevoda: odomashnivanie morskih grebeshkov i rybakov zaliva Sen-Brijo [Some elements of the sociology of translation]//Sociologija vlasti [Sociology of Power], vol. 27, no 1, pp. 196-231. (in Russian)

«Komsomolka» nachinaet akciju «Spasem bruschatku starogo goroda!» (2010) [The komsomolka started the action "Save the cobblestones of the old city!"]. Komsomol'skaja pravda. Kaliningrad. [Komsomolskaya Pravda. Kaliningrad]. Available at: https://www.kaliningrad.kp.ru/daily/24587/756920/ (accessed 18 May 2020). (in Russian)

Latur B. (2002) Dajte mne laboratoriju, i ja perevernu mir [Give me a laboratory and I will change the world]. Logos [Logos], vol. 35, no 5-6, pp.1-32. (in Russian)

Lemieux C. (2018) La Sociologie Pragmatique. Paris : La Découverte.

Low S.M. (2000) On the Plaza: The Politics of Public Space and Culture. Austin: University of Texas Press.

Marres N. (2007) The issues Deserve More Credit: Pragmatist Contributions to the Study of Public Involvement in Controversy. Social studies of science, vol. 37, no 5, pp. 759-780.

Novozhilova T. «Na bruschatke pod dozhdem»: reportazh «Novogo Kaliningrada.Ru» s ulicy Tel'mana [On the cobblestones under the rain]. Komsomol'skaja Pravda. Kaliningrad [Komsomolskaya Pravda. Kaliningrad]. Available at: https://www.newkaliningrad.ru/news/community/1642687-na-bruschatke-pod-dozhdem-reportazh-novogokaliningradaru-s-ulitsy-telmana.html (accessed 18 May 2020). (in Russian)

Obrashhenie o statuse bruschatogo pokrytija kak jelementa istoriko-kul'turnogo nasledija Kaliningradskoj oblasti [Appeal on the status of paving as an element of the historical and cultural heritage of the Kaliningrad region] (2012). Available at: https://docs.google.com/forms/d/e/1FAlpQLSdVJ0jqsh_XsGw-aUW4KyhAkClingJSVY7CHK oG7LDSPpfpgw/viewform?formkey=dHc0blhQMjBmLTBqOE9Rc2FXN3BvZFE6MQ (accessed 18 May 2020). (in Russian)

Oprosy. Goradministracija Kaliningrada. Available at: https://www.klgd.ru/vote/index.php (accessed 18 May 2020). (in Russian)

Pro bruschatku [On the Cobblestones]. Livejournal. Available at: https://yaroshuk.livejournal.com/?skip=10 (accessed 18 May 2020). (in Russian)

Savkin G. (2013) Bruschatka nasmarku? [Do away with the cobblestones?]. Izdanie «Dvornik» [Dvornik Periodical]. Available at: http://www.dvornik.ru/issue/868/28922/?sphrase_id=230534 (accessed 18 May 2020). (in Russian)

Sostavim spisok ulic, gde sohranilas' bruschatka (2011) [Make up a list where the cobblestones remain]. Izdanie «Klops» [Klops Periodical]. Available at: https://klops.ru/news/obschestvo/34228-sostavim-spisok-ulits-gdesohranilas-bruschatka (accessed 18 May 2020). (in Russian)

Thévenot L. (2006) L'action au pluriel. Sociologie des regimes d'engagement. Paris: La Découverte.

Tykanova E.V. (2013) Strategii i taktiki osparivanija gorodskogo prostranstva gruppami interesov (na primere konfliktov vokrug gorodskogo razvitija $v$ Sankt-Peterburge) [Strategies and tactics of the negotiations of the urban spaces by the groups of interests]. Vestnik Sankt-Peterburgskogo universiteta. Serija 12. Sociologija [Vestnik of Saint Petersburg University. Sociology]., vol. 1, pp. 103-110. (in Russian)

Tykanova E., Khokhlova A. (2015) The Performative Logic of Urban Space Contestation: Two Examples of Local Community Mobilisation in St. Petersburg. Jacobsson K. (ed.) Urban Grassroots Movements in Central and Eastern Europe. Abingdon: Ashgate, pp. 139-162.

Tykanova E., Khokhlova A. (2019) Grassroots Urban Protests in St. Petersburg: (Non)Participation in Decision-Making on the Futures of City Territories. International Journal of Politics, Culture and Society, vol. 33, 1-22.

Vlasti predlagajut «raz i navsegda» opredelit', gde ostavljat' bruschatku (2011) [The authorities propose to determine the fate of the cobble stones]. Novyj Kaliningrad [New Kaliningrad]. Available at: https://www.newkaliningrad. ru/special/roadholes/1287534-vlasti-predlagayut-raz-i-navsegda-opredelit-gde-ostavlyat-bruschatku.html (accessed 18 May 2020). (in Russian)

Williams R. (1983) Culture and society, 1780-1950. Columbia University Press. 